\title{
Spectroscopic Insight into Tetrahedrally Distorted Square Planar Copper(II) Complex: XRD/HSA, Physicochemical, DFT, and Thermal Investigations
}

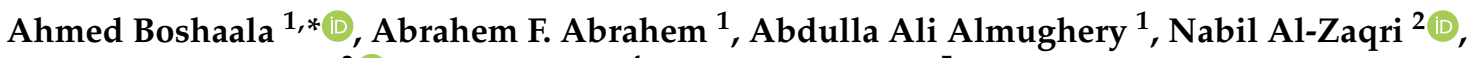 \\ Abdelkader Zarrouk ${ }^{3}$ D , Hassane Lgaz $^{4}$ and Ismail Warad ${ }^{5, *}$ \\ 1 Libyan Authority for Scientific Research, Tripoli P.O. Box 80045, Libya; abrahemff@hotmail.com (A.F.A.); \\ a_almughery@yahoo.co.uk (A.A.A.) \\ 2 Department of Chemistry, College of Science, King Saud University, P.O. Box 2455, Riyadh 11451, \\ Saudi Arabia; nalzaqri@ksu.edu.sa \\ 3 Laboratory of Materials, Nanotechnology and Environment, Faculty of Sciences, Mohammed V University in \\ Rabat, Agdal-Rabat P.O. Box 1014, Morocco; azarrouk@gmail.com \\ 4 Department of Architectural Engineering, Hanyang University-ERICA, Sangnok-gu, Ansan 15588, Korea; \\ hlgaz@konkuk.ac.kr \\ 5 Department of Chemistry and Earth Sciences, College of Arts and Sciences, Qatar University, \\ Doha P.O. Box 2713, Qatar \\ * Correspondence: ahmedboshaala@yahoo.co.uk (A.B.); ismail.warad@qu.edu.qa (I.W.)
}

\section{check for} updates

Citation: Boshaala, A.; Abrahem, A.F.; Almughery, A.A.; Al-Zaqri, N.; Zarrouk, A.; Lgaz, H.; Warad, I. Spectroscopic Insight into Tetrahedrally Distorted Square Planar Copper(II) Complex: XRD/HSA, Physicochemical, DFT, and Thermal Investigations. Crystals 2021, 11, 1179. https://doi.org/10.3390/ cryst11101179

Academic Editor: Vladimir Fedin

Received: 27 August 2021

Accepted: 15 September 2021

Published: 28 September 2021

Publisher's Note: MDPI stays neutral with regard to jurisdictional claims in published maps and institutional affiliations.

Copyright: (c) 2021 by the authors. Licensee MDPI, Basel, Switzerland. This article is an open access article distributed under the terms and conditions of the Creative Commons Attribution (CC BY) license (https:/ / creativecommons.org/licenses/by/ $4.0 /)$.

\begin{abstract}
The reaction of bidentate N-S-thione-Schiff base, (E)-benzyl 2-(1-(4-chlorophenyl)ethylidene)hydrazinecarbodithioate, with $\mathrm{Cu}\left(\mathrm{NO}_{3}\right)_{2} \cdot 3 \mathrm{H}_{2} \mathrm{O}$ produced a cis-Cu(II) complex. The molecular structure was confirmed and characterized by CHN-EA, FAB-MS, IR, and UV-Vis analyses. The XRD supported cis-isomer of the bis anionic bidentate $\mathrm{N}$ (azomethine) and $\mathrm{S}$ (thiol) ligand coordination mode in tetrahedrally distorted square planar, rarely reported in the literature. The results of the XRD-bond lengths were in perfect agreement with the density functional theory (DFT) calculation. DFT-calculated angles around the $\mathrm{Cu}(\mathrm{II})$ center displayed slightly less distortion around the metal center from those of XRD. Additionally, the thermal stability of the complex was evaluated via thermal gravimetric analysis (TGA). Two-dimensional fingerprint (2D-FP), Hirshfeld surface analysis (HSA), and molecular electrostatic potential (MEP) support the XRD-packing results with the existence of the $\mathrm{H} \cdots \mathrm{Cl}$ and $\mathrm{CH} \cdots \pi$ bonds as the main interactions in the crystal lattice of the desired complex.
\end{abstract}

Keywords: Copper(II); DFT; hydrazonodithioate; tetrahedrally distorted square planar; Hirshfeld surface analysis

\section{Introduction}

Recently, a wide spectrum of nitrogen- and sulfur-including ligands like dithiocarbazates, thiosemicarbazones, and dithiocarbamates with their metal ion complexes have experienced supplementary interest in the field of medicine and pharmacology due to their potent applications, such as antibacterial, antiviral, antitumor, antifungal, and antiparasitic activities [1-8]. The structural variation on hydrazinecarbodithioate Schiff base derivatives, $\mathrm{R}-\mathrm{CH}=\mathrm{N}-\mathrm{NH}-\mathrm{C}(=\mathrm{S})-\mathrm{S}-\mathrm{NHR}$, can be easily modified through the replacement of $\mathrm{R}$ groups in the synthetic steps. Therefore, a broad selection of N,N or N,S and N,N,S or N,N,N as bidentate, tridentate, and even polydentate ligands has been prepared for medicinal and industrial application as well as for evaluating the coordination modes with transition metals [9-20]. The hydrazinecarbodithioate Schiff bases derived from S-acetyl, S-alkyl, S-methyl dithiocarbazates, and dithiocarbazate represent the preponderance of advanced reports available on the Cambridge Structural Database. However, only a limited number are accessible on hydrazinecarbodithioate with substituted S-benzyl moiety along with 
their organometallic complexes [8-14]. Despite the fact that coordinated hydrazinecarbodithioate Schiff bases to transition metals are scarcely reported and demonstrated on compared to the free ligands, full characterization by XRD analysis is highly demanded in order to obtain a real structural vision.

The spatial arrangement of four coordinated groups around the metal center offers several geometries, mostly regular tetrahedral, occasionally square planar, and rarely tetrahedrally distorted square planar, resulting in either increasing the bond angles (elongated tetrahedron) or decreasing the angles (flattened tetrahedron) [21-23]. Furthermore, a square planar molecular geometry could be created once the four groups are located at the corners of a square in the same plane of the central metal, with the possibility of possessing cis or trans conformation, e.g., $\mathrm{M}(\mathrm{N}, \mathrm{S})_{2}$, in which $\mathrm{N}, \mathrm{S}$ is a bidentate ligand. Quite rarely, a hybrid molecular geometry, namely, a tetrahedrally distorted square planar shape, can be formed due to the distorted coordinated ligand moieties to the metal center [22,23]. Thus, structural elucidation by XRD analysis offers an excellent level of characterization of the geometry around metal complexes.

Herein, we depict the synthesis of tetrahedrally distorted square planar complexes, rising from the in situ tautomerization of hydrazine-1-carbodithioate derivative and subsequent coordination with $\mathrm{Cu}\left(\mathrm{NO}_{3}\right)_{2} \cdot 3 \mathrm{H}_{2} \mathrm{O}$ after deprotonating the thiol group in the absence of base. The new $\mathrm{Cu}(\mathrm{II})$ complex was fully described by $\mathrm{XRD}$, revealing a cis conformation of the two coordinated ligands to the metal ion. Furthermore, the thermal behavior, physicochemical properties, Hirshfeld surface analysis (HSA), and density functional theory (DFT) simulations were investigated and demonstrated.

\section{Experimental}

\subsection{Computational}

HSA was executed using the CrystalExplorer software, version 17 (version 17, University of Western Australia, Perth, Australia) [24]. Gaussian W09 Revision E.01 software [25] was employed for all DFT operations. Optimization and frequency calculations were performed in gaseous state using LanL2DZ basis set for the copper metal, whereas 6-311G(d,p) was designated for all other atoms.

\subsection{Materials and Synthesis}

Fine chemicals and solvents were received from the supplier of reagent grade and used directly without further purification. Hydrazine hydrate (90\%), carbon disulphide, $\mathrm{Cu}(\mathrm{II})$ nitrate trihydrate, and potassium hydroxide were procured from Honeywell Fluka ${ }^{\mathrm{TM}}$, while benzyl chloride and 4-chloroacetophenone were acquired from Manchester Salt and Catalysis Ltd. PerkinElmer Spectrum 1000 FT-IR Spectrometer (PerkinElmer Inc., Waltham, MA, USA) was employed to record the infrared absorption in the wavenumber range of $4000-200 \mathrm{~cm}^{-1}$ in solid state. The UV-Vis measurements were accomplished in methanol solvent using TU-1901 (Purkinje General Instrument Co., Ltd., Beijing, China) double-beam spectrophotometer. The $\mathrm{CHN}$ analysis was measured using an Elementar Analyzer Varrio EL (Elementar Analysensysteme GmbH, Langenselbold, Germany).

\subsection{Synthesis of Copper(II) Complex}

First, $0.483 \mathrm{~g}(2 \mathrm{mmol})$ of $\mathrm{Cu}\left(\mathrm{NO}_{3}\right)_{2} \cdot 3 \mathrm{H}_{2} \mathrm{O}$ in ethanol $(20 \mathrm{~mL})$ solution was added to a hot solution of $1.340 \mathrm{~g}(4 \mathrm{mmol})$, benzyl (E)-2-(1-(4-chlorophenyl)ethylidene)-hydrazine-1carbodithioate ligand in $40 \mathrm{~mL}$ of ethanol, where the resulting solution was stirred for one hour. Subsequently, the volume was reduced by one-half and cooled in a refrigerator for about $24 \mathrm{~h}$. The brownish precipitate was separated, washed with ethanol, and dried. The required crystals for XRD were obtained by crystallization from chloroform $(25 \mathrm{~mL})$ in the presence of a few drops of $n$-hexane at room temperature for 3 weeks. The deep-brown solid decomposed at $190{ }^{\circ} \mathrm{C}$ and its yield was $86 \%$. Anal. Calcd as $\mathrm{C}_{32} \mathrm{H}_{28} \mathrm{Cl}_{2} \mathrm{CuN}_{4} \mathrm{~S}_{4}$ : C, 52.56; H, 3.86; N, 7.66. Found: C, 52.71; H, 3.77; N, 7.53. FAB-MS: $m / z(\%)=730.9$, theoretically: 731.3. Selected IR data $\left(\mathrm{KBr}\right.$ disk, $\left.\mathrm{cm}^{-1}\right): v(\mathrm{C}-\mathrm{H}, \mathrm{Ph}) 3060, v(\mathrm{C}=\mathrm{N}) 1406$, 
$v(\mathrm{~N}-\mathrm{N}) 1117, v(\mathrm{CSS}) 825, v(\mathrm{Cu}-\mathrm{N})$ 619. UV-Vis: Ligand bands such as $\pi$ to $\pi^{*}$ at 238, 290, 318 , and $397 \mathrm{~nm}$, and ligand-to-metal charge transfer (LMCT) band at $455 \mathrm{~nm}$.

\subsection{XRD-Structure}

A single crystal was fixed on a glass fiber for measurement, in which all crystallographic data were accomplished on a Bruker-AXS-SMART APEX CCD diffractometer (Bruker $\mathrm{GmbH}$, Berlin, Germany). by means of Mo-K $\alpha$ radiation $\left(\lambda=0.71073 \mathrm{~A}^{\circ}\right)$ and the data were gathered at a temp. of $130 \pm 2 \mathrm{~K}$ using the scanning technique to a maximum of $\theta=27.87^{\circ}$. The structures were resolved by direct technique using SIR-92 and refined by full-matrix least squares [26]. Non-hydrogen bond atoms were refined anisotropically via SHELXL [27]. Hydrogen atoms were positioned geometrically and refined isotropically. Detailed crystal data and refinement of the structure are reported and depicted in Table 1.

Table 1. Structure refinement and crystal data and of $\mathrm{Cu}$ (II) complex.

\begin{tabular}{|c|c|}
\hline Chemical Formula & $\mathrm{C}_{32} \mathrm{H}_{28} \mathrm{Cl}_{2} \mathrm{CuN}_{4} \mathrm{~S}_{4}$ \\
\hline CCDC No. & $1,503,558$ \\
\hline $\mathrm{Mr}$ & 731.26 \\
\hline Crystal system, space group & Triclinic, $\mathrm{P}-1$ \\
\hline Temperature K & 130 \\
\hline$a, b, c(\AA)$ & $9.5051(11), 13.7130(16), 14.3488(16)$ \\
\hline$\alpha, \beta, \gamma\left({ }^{\circ}\right)$ & $63.012(2), 75.674(2), 89.656(2)$ \\
\hline$V\left(\AA^{3}\right)$ & $1602.5(3)$ \\
\hline Z & 2 \\
\hline$\mu\left(\mathrm{mm}^{-1}\right)$ & 1.14 \\
\hline Radiation type & Mo-K $\alpha$ \\
\hline Crystal size (mm) & $0.41 \times 0.20 \times 0.18$ \\
\hline $\begin{array}{l}\text { No. of measured, independent and observed }[I>2.0 \sigma(I)] \\
\text { reflections }\end{array}$ & $15,300,7589,6391$ \\
\hline$R_{\text {int }}$ & 0.023 \\
\hline$T_{\min }, T_{\max }$ & $0.652,0.821$ \\
\hline$(\sin \theta / \lambda)_{\max }\left(\AA^{-1}\right)$ & 0.658 \\
\hline$R\left[F^{2}>2 \sigma\left(F^{2}\right)\right], w R\left(F^{2}\right), S$ & $0.034,0.087,1.04$ \\
\hline No. of reflections, No. of parameters & 7589,390 \\
\hline$\Delta \rho_{\max }, \Delta \rho_{\min }\left(\mathrm{e} \AA^{-3}\right)$ & $0.62,-0.34$ \\
\hline
\end{tabular}

\section{Results and Discussion}

\subsection{Synthesis of Copper(II) Complex}

The $\mathrm{Cu}(\mathrm{II})$ complex was prepared by combining two equivalents of free ligand, benzyl (E)-2-(1-(4-chlorophenyl)ethylidene)hydrazine-1-carbodithioate, with one equivalent of $\mathrm{Cu}\left(\mathrm{NO}_{3}\right)_{2} \cdot 3 \mathrm{H}_{2} \mathrm{O}$ in ethanolic solution [28]. The free thione form of the ligand was subjected to tautomerization to a thiol form [29], (1E,1E)-benzyl hydrogen (1-(4chlorophenyl)ethylidene)carbonhydrazonodithioate, in the solution prior to coordination to the copper metal center. Remarkably, the thione form was an additional stable structure in the solid state [30]. Copper(II) complex was isolated as brown powder and recrystallized from chloroform in the presence of trace amounts of hexane, yielding X-ray quality crystals, the bis[(1E,1E)-benzyl(1-(4-chlorophenyl)ethylidene)-carbonhydrazonodithioate]copper(II) in cis conformation, as in Scheme 1. The XRD analysis reflected a bidentate ligand coordinated through $\mathrm{N}$ (azomethine) and $\mathrm{S}$ (thiol) to the metal center, giving a solely neutral water-soluble complex.

The new copper complex was characterized by elemental analysis, revealing strong agreement with the expected $\mathrm{C}_{32} \mathrm{H}_{28} \mathrm{Cl}_{2} \mathrm{CuN}_{4} \mathrm{~S}_{4}$ formula. On the other hand, fast atom bombardment mass spectroscopy (FAB-MS) was used to pursue the molecular weight of the desired complex (Figure 1), giving a value of $730.9 \mathrm{~m} / \mathrm{z}$ which was quite close to the theoretical assessment $(731.3 \mathrm{~m} / \mathrm{z})$. These analyses support the general molecular formula of the anticipated $\mathrm{Cu}(\mathrm{II})$ complex. 
<smiles>CC(=NNC(=S)SCc1ccccc1)c1ccc(Cl)cc1</smiles>

Scheme 1. Synthesis of $\mathrm{Cu}(\mathrm{II})$ complex synthesis.

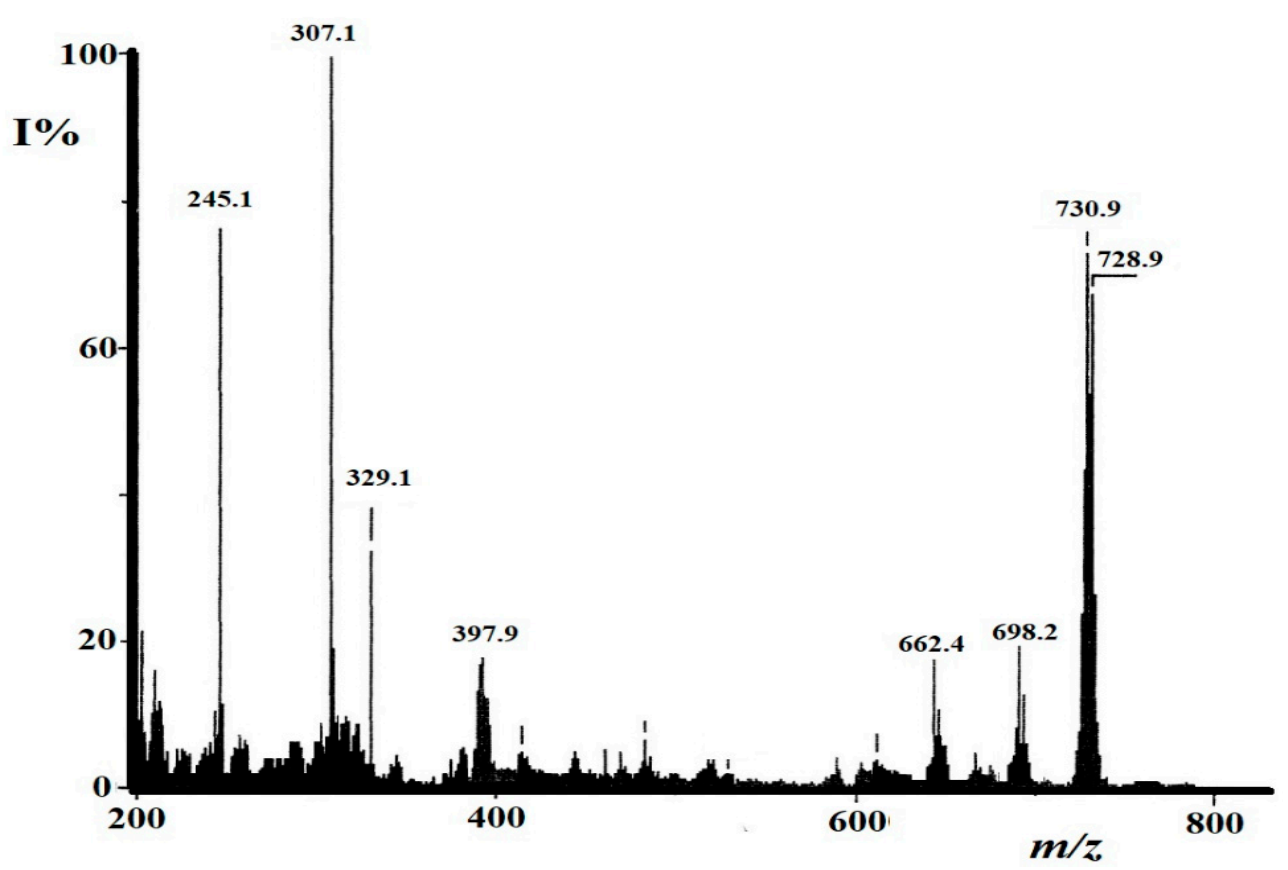

Figure 1. FAB-MS of the desired $\mathrm{Cu}$ (II) complex.

\subsection{Infrared and Electronic Absorption Spectra}

The solid-state FTIR data of the desired complex displayed few sets of absorption bands for the typical functional groups present in the structure (Figure 2a). The experimental absorption bands in the range of $3015-3110 \mathrm{~cm}^{-1}$ were assigned to aromatic $\mathrm{CH}$-stretching vibrations, while the stretching mode at $2980 \mathrm{~cm}^{-1}$ were attributed to aliphatic $\mathrm{CH}$ vibration. The absence of free $\mathrm{NH}$ and $\mathrm{SH}$ absorptions in the region of $\sim 3350$ and $2600 \mathrm{~cm}^{-1}$, respectively, indicates the coordination of the free ligand to the copper metal center in a deprotonated form. A weak-stretching vibration at $1605 \mathrm{~cm}^{-1}$ was assigned to a conjugated $C=N$. Further absorption bands included $C-C, C=C, C-N$, and $C-S$. On the other hand, the simulated DFT-FTIR (Figure $2 b$ ) of the new complex revealed a sophisticated level of agreement with experimental results; the graphical correlation value $\left(R^{2}\right)$ was found to be 0.998 , as seen in Figure 2c. 


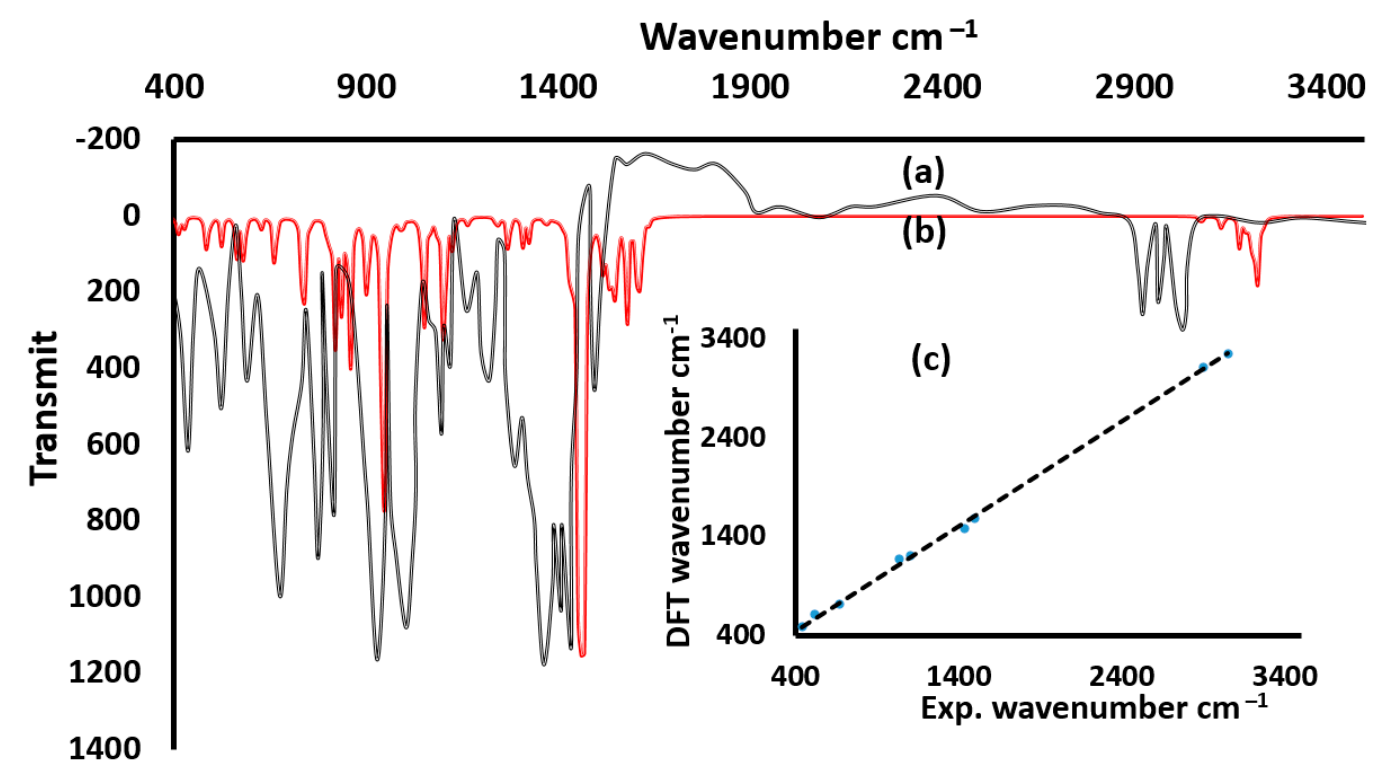

Figure 2. FTIR of cis-Cu(II) complex: experimental (a), DFT (b) and graphical correlation (c).

The experimental and time-dependent TD-DFT electronic absorption spectra of the synthesized copper complex was acquired in a spectral range of 200-800 nm. A solution of the complex in methanol displayed two bands in the UV area at $\lambda_{\max }=260 \mathrm{~nm}$ and $315 \mathrm{~nm}$ (resulting from $\pi-\pi^{*}$ electron transfer) and a single band at $\lambda_{\max }=360 \mathrm{~nm}$, which could be attributed to the $n-\pi^{*}$ electron transfer. Furthermore, a broad band possessing $\lambda_{\max }=515 \mathrm{~nm}$ verified in the visible area can be ascribed to the ligand-to-metal charge transfer as seen in Figure 3a. The simulated electronic spectrum was accomplished using a TD-SCF/DFT/CAM-B3LYP method and 6-31G as basis set in methanol (Figure 3b) [31,32]. A wide band appeared at $\lambda_{\max }=330 \mathrm{~nm}$ with three electron transition lines at $262 \mathrm{~nm}$, $330 \mathrm{~nm}$, and $375 \mathrm{~nm}$, almost covering the three experimental absorptions. A very broad band was estimated at $\lambda_{\max }=560 \mathrm{~nm}$ with $\Delta \lambda=45 \mathrm{~nm}$ of bathochromic shift compared to the same experimental band.

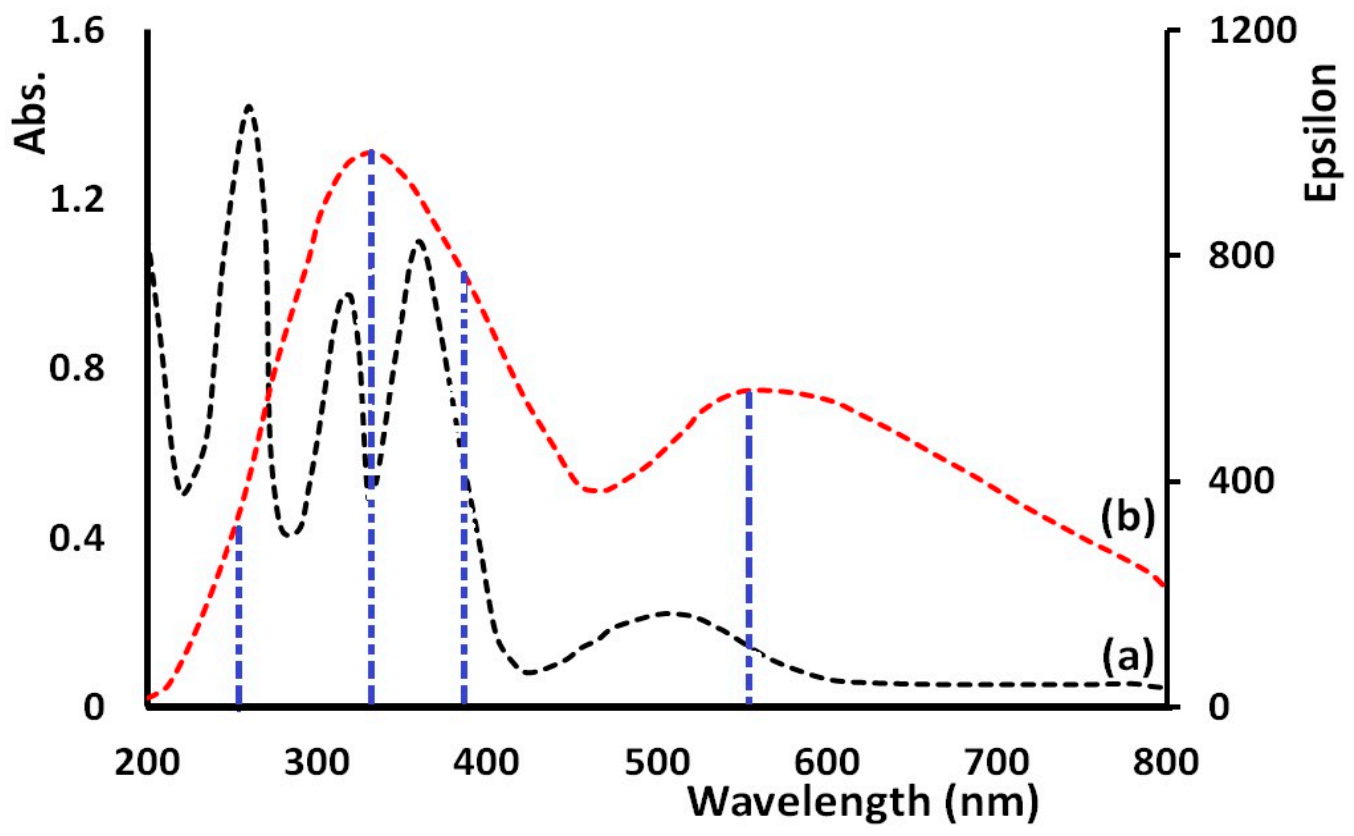

Figure 3. FTIR of cis-Cu(II) complex: experimental (a) and DFT (b). 


\section{3. $X R D$ and $D F T$}

The ORTEP- and DFT-optimized structure diagrams of the cis-Cu(II) complex together with selected structural parameters are illustrated in Figure 4 and Table 2. The crystal structure of $\mathrm{C}_{32} \mathrm{H}_{28} \mathrm{Cl}_{2} \mathrm{CuN}_{4} \mathrm{~S}_{4}$ is a triclinic system with P-1 space group. The full crystallographic data of the desired complex have been reported [33]. The two ligands coordinated to the $\mathrm{Cu}(\mathrm{II})$ metal center via $\mathrm{N}, \mathrm{S}$ provided by two anionic $\mathrm{S}^{-}$and two unsaturated $\mathrm{N}$ groups to form the neutral bis[(1E,1E)-benzyl(1-(4-chlorophenyl)ethylidene)carbonhydrazonodithioate]copper(II) complex in cis isomer with two metal five-membered $\mathrm{Cu}(\mathrm{S}, \mathrm{N})_{2}$ rings (Figure $4 \mathrm{~b}$ ). It should be noted as well that the trans isomer was not detected at all.

The angles and bond lengths of the desired complex were in a good agreement with similar structures reported previously [9-20]. The geometry around the $\mathrm{Cu}$ (II) center featured a tetrahedrally distorted square planar with a torsional angle, $\tau_{(\mathrm{N} 1-\mathrm{N} 3-\mathrm{S} 3-\mathrm{S} 1)}=$ $40.7^{\circ}$ (Figure $4 \mathrm{~b}$ ). Based on the DFT optimization of the anticipated complex, the free ligand was coordinated in a deprotonated form, reflecting a neutral structure (Figure 4c,d) with slightly less distortion around $\left(\tau=37.5^{\circ}\right)$ around the $\mathrm{Cu}(\mathrm{II})$ complex. The level of distortion in DFT calculations were anticipated as geometry optimization performed in a gaseous phase with the absence of intermolecular forces. However, the experimental XRD was performed in solid state in the presence of several types of molecular interactions in the complex lattice. Thus, we highly expected the geometry to be a tetrahedrally distorted square planar, or in other words, the geometry around the copper center could be superiorly described as a square-planar arrangement, exhibiting a tenuous tetrahedral distortion. The DFT calculation additionally showed that the cis-Cu(II) isomer is a stable isomer, since this conformation is kinetically favored and its global energy of formation is less than the thermodynamically favored isomer, trans-form [34].

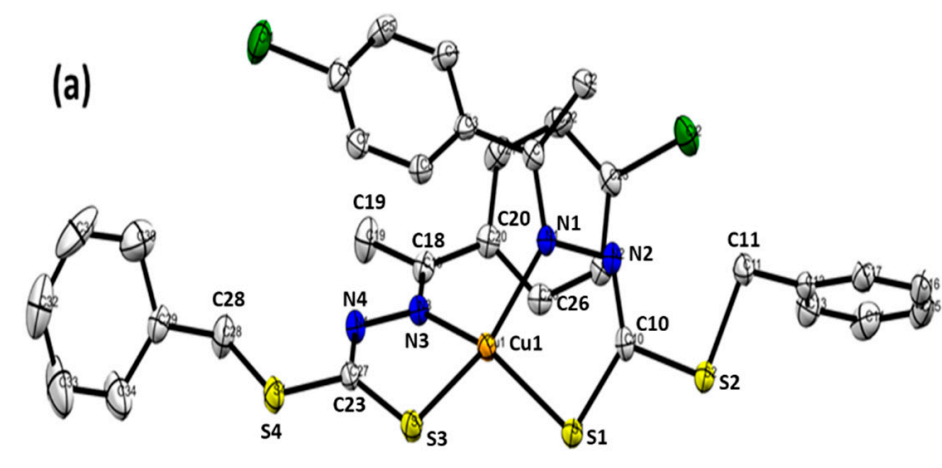

(b)

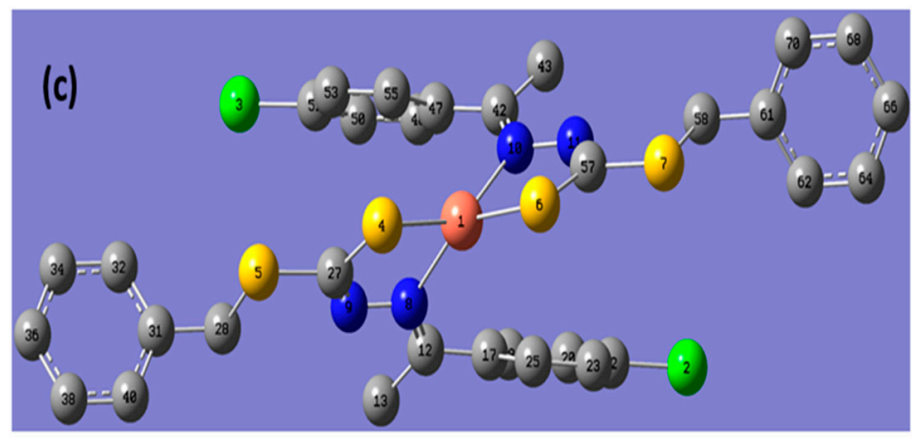

(d)

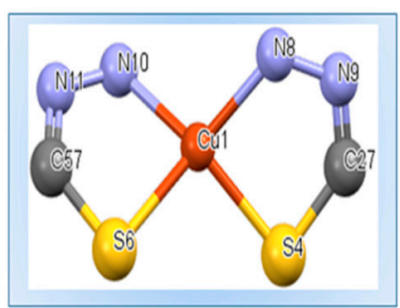

Figure 4. ORTEP at 20\% probability level (a), XRD tetrahedrally distorted square planar (b), DFT optimization (c), and DFT tetrahedral structure of cis-Cu(II) complex (d).

The DFT-optimized bond lengths and angles were set in a relation with the values resulting from the experimental XRD (Figure 5). A high level of consistency between the values of DFT and XRD in terms of bond lengths were observed (Figure 5a) with graphical correlation $R^{2}=0.995$ (Figure $5 b$ ). However, bond angles obtained from these two approaches were clearly not in a very good harmonization, in which $R^{2}=0.987$ (Figure $5 c, d$ ). 
This difference in angle values is due to the difference in the level of distortion around the $\mathrm{Cu}(\mathrm{II})$ center, optimized by DFT and measured by XRD.
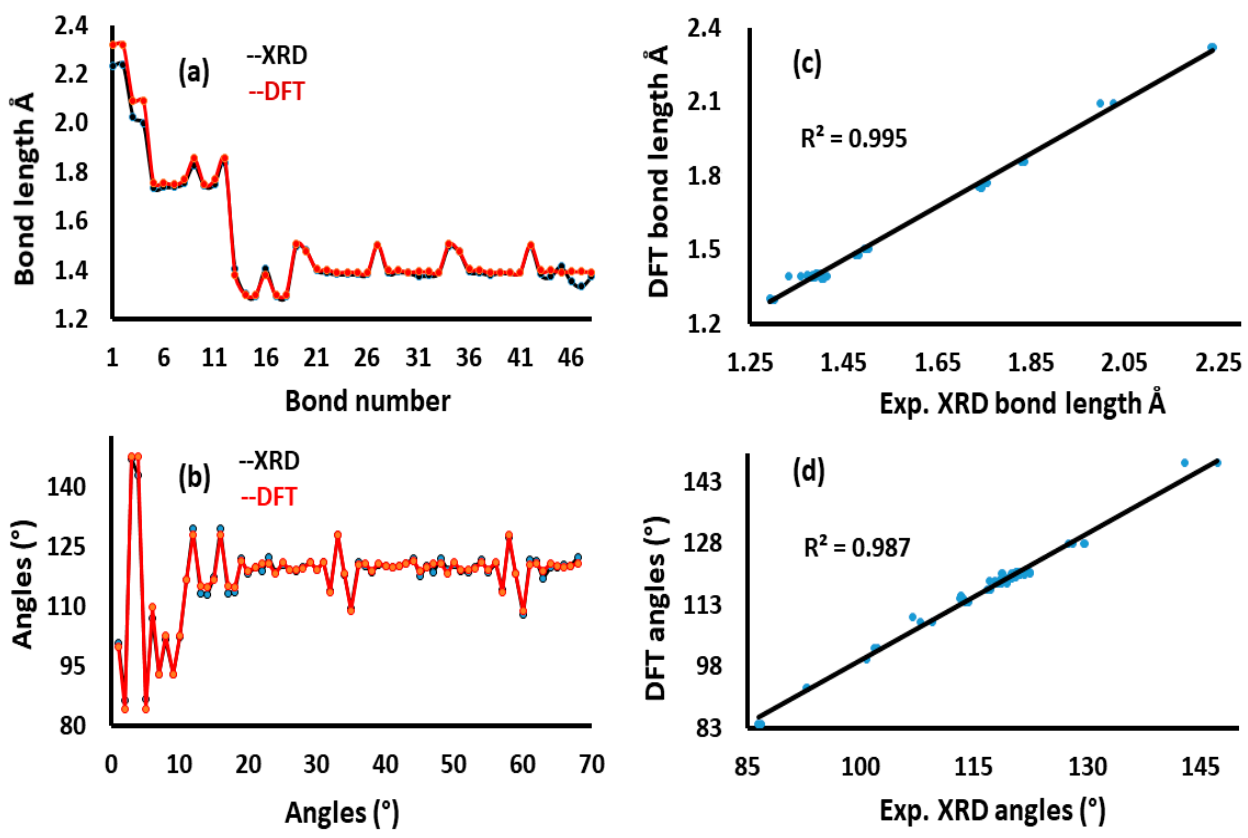

Figure 5. XRD/density functional theory (DFT) histogram of bond lengths (a), XRD/DFT graphical correlation for bond lengths (b), DFT/XRD angles histogram (c), and XRD/DFT graphical correlation for angles (d).

Table 2. Designated XRD/DFT bond lengths and angles.

\begin{tabular}{|c|c|c|c|c|c|c|c|c|c|}
\hline \multirow{3}{*}{$\begin{array}{c}\text { No. } \\
1\end{array}$} & \multirow{2}{*}{\multicolumn{2}{|c|}{ Bond Type }} & \multicolumn{2}{|c|}{ Bond Length [Å] } & \multirow{2}{*}{\multicolumn{3}{|c|}{ Angle Type }} & \multicolumn{2}{|c|}{ Angle Value $\left({ }^{\circ}\right)$} \\
\hline & & & \multirow{2}{*}{$\begin{array}{l}\text { XRD } \\
2.235\end{array}$} & \multirow{2}{*}{$\begin{array}{l}\text { DFT } \\
2.320\end{array}$} & & & & XRD & DFT \\
\hline & $\mathrm{Cu} 1$ & $\mathrm{~S} 1$ & & & S1 & $\mathrm{Cu} 1$ & S3 & 100.7 & 99.7 \\
\hline 2 & $\mathrm{Cu} 1$ & S3 & 2.239 & 2.320 & S1 & $\mathrm{Cu} 1$ & N1 & 86.4 & 84.1 \\
\hline 3 & $\mathrm{Cu} 1$ & N1 & 2.025 & 2.093 & S1 & Cu1 & N3 & 147.2 & 147.6 \\
\hline 4 & $\mathrm{Cu} 1$ & N3 & 1.999 & 2.093 & S3 & $\mathrm{Cu} 1$ & N1 & 142.9 & 147.6 \\
\hline 5 & $\mathrm{Cl} 1$ & C6 & 1.738 & 1.757 & S3 & Cu1 & N3 & 86.8 & 84.1 \\
\hline 6 & $\mathrm{Cl} 2$ & $\mathrm{C} 23$ & 1.739 & 1.757 & N1 & $\mathrm{Cu} 1$ & N3 & 106.9 & 109.9 \\
\hline 7 & S1 & $\mathrm{C} 10$ & 1.742 & 1.750 & Cu1 & S1 & $\mathrm{C} 10$ & 93.0 & 92.8 \\
\hline 8 & S2 & $\mathrm{C} 10$ & 1.756 & 1.769 & $\mathrm{C} 10$ & $\mathrm{~S} 2$ & C11 & 101.8 & 102.5 \\
\hline 9 & S2 & C11 & 1.829 & 1.855 & Cu1 & S3 & $\mathrm{C} 27$ & 92.8 & 92.8 \\
\hline 10 & S3 & $\mathrm{C} 27$ & 1.744 & 1.750 & C27 & S4 & C28 & 102.2 & 102.5 \\
\hline 11 & S4 & C27 & 1.752 & 1.769 & Cu1 & N1 & N2 & 116.7 & 116.7 \\
\hline 12 & S4 & C28 & 1.836 & 1.855 & Cu1 & N1 & $\mathrm{C} 1$ & 129.6 & 127.9 \\
\hline 13 & N1 & N2 & 1.407 & 1.381 & N2 & N1 & $\mathrm{C} 1$ & 113.3 & 115.3 \\
\hline 14 & N1 & C1 & 1.302 & 1.299 & N1 & N2 & C10 & 113.1 & 114.7 \\
\hline 15 & N2 & C10 & 1.293 & 1.300 & Cu1 & N3 & N4 & 117.2 & 116.7 \\
\hline 16 & N3 & $\mathrm{N} 4$ & 1.403 & 1.381 & Cu1 & N3 & C18 & 129.5 & 127.9 \\
\hline 17 & N3 & C18 & 1.295 & 1.299 & $\mathrm{~N} 4$ & N3 & C18 & 113.2 & 115.2 \\
\hline 18 & N4 & C27 & 1.292 & 1.300 & N3 & N4 & C27 & 113.6 & 114.7 \\
\hline 19 & $\mathrm{C} 1$ & $\mathrm{C} 2$ & 1.498 & 1.505 & N1 & $\mathrm{C} 1$ & $\mathrm{C} 2$ & 122.0 & 121.5 \\
\hline 20 & $\mathrm{C} 1$ & C3 & 1.481 & 1.478 & N1 & $\mathrm{C} 1$ & C3 & 118.3 & 118.8 \\
\hline
\end{tabular}

\subsection{XRD Packing, HSA, and Molecular Electrostatic Potential (MEP) Investigation}

Five types of short contacts were detected in the lattice of the cis-Cu(II) complex; all interactions are packed together with cell axes as illustrated in Figure 6a. No classical hydrogen bonding could be found; the shorter hydrogen bond of the type $\mathrm{C}_{\mathrm{Ph}}-\mathrm{H} \cdots \mathrm{Cl}$ with $2.842 \AA$ reflected a one-dimensional supramolecular chain formation (Figure $6 \mathrm{~b}$ ). However, an $\mathrm{R}(38)$ motif was constructed by two $\mathrm{C}_{\mathrm{ph}}-\mathrm{H} \cdots \pi \mathrm{Ph}$ with a value of $2.860 \AA$ (Figure $6 \mathrm{c}$ ) 
and an $\mathrm{R}(8)$ motif was detected via $-\mathrm{CH} \cdots \pi \mathrm{C}=\mathrm{N}$ with $2.811 \AA$ (Figure $6 \mathrm{~d}$ ). Two different classical $\mathrm{CH} \cdots \pi$ bonds were stabilized by the same phenyl ring via $\mathrm{C}_{\mathrm{ph}}-\mathrm{H} \cdots \pi \mathrm{Ph}$ with $2.828 \AA$ (Figure 6e), another interaction was categorized as a classical $\mathrm{C}_{\mathrm{ph}}-\mathrm{H} \cdots \pi \mathrm{Ph}$ with $2.884 \AA$ (Figure $6 \mathrm{f}$ ), and the last type of interaction was $\pi \ldots \pi$ stack interaction in C3-C8 with $3.72 \AA$ bond length as seen in Figure $6 \mathrm{~g}$.
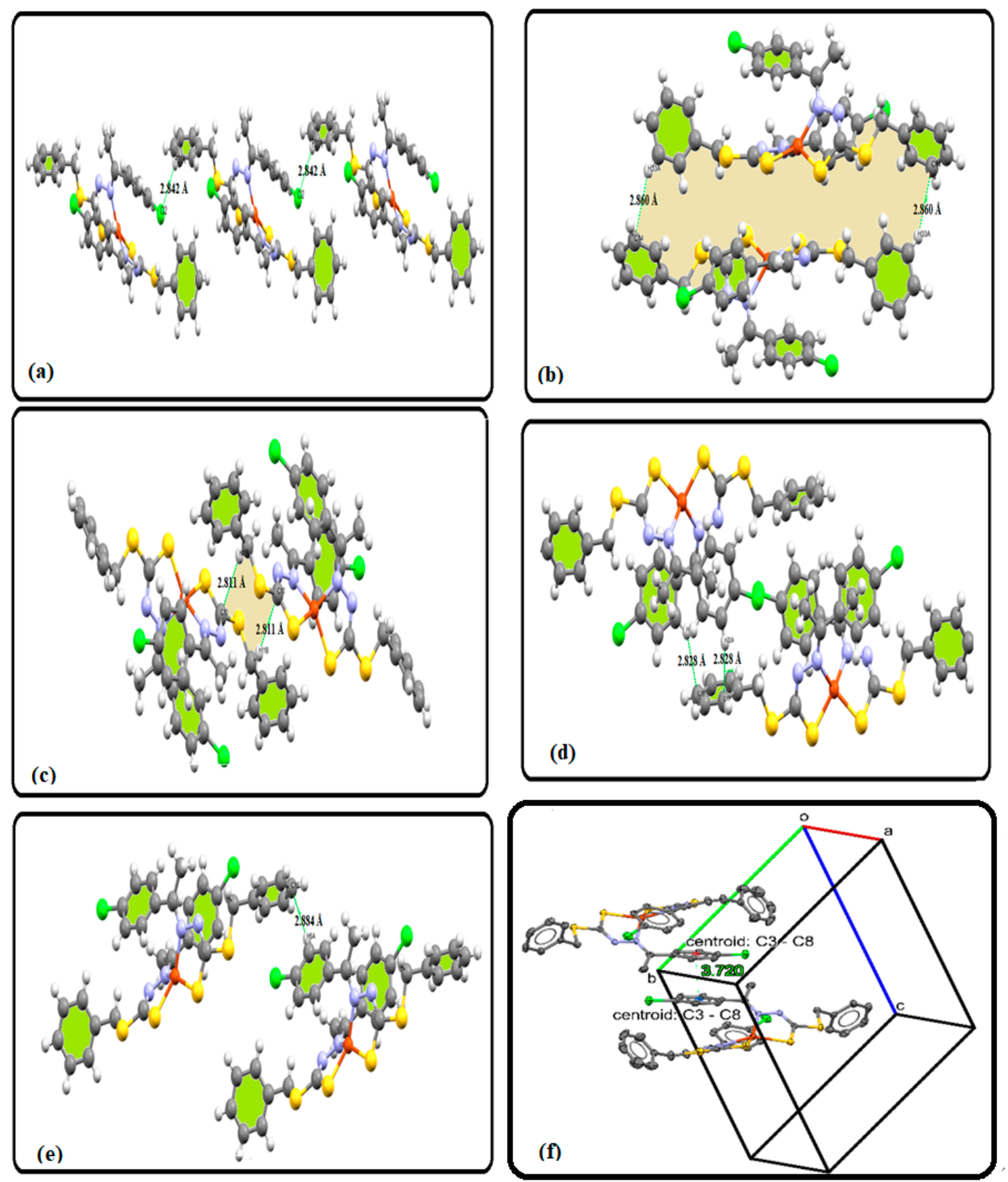

Figure 6. Total interaction in the lattice of cis-Cu(II) complex: One-dimensional supramolecular chain formation (a), R(38) motif (b), $\mathrm{R}(8)$ motif (c), classical $\mathrm{CH} \cdots \pi$ bond short contacts $(\mathbf{d})$, classical $\mathrm{C}_{\mathrm{ph}}-\mathrm{H} \cdots \pi \mathrm{Ph}$ short contacts (e), and antiparallel $\pi \cdots \pi$ stack interaction $(\mathbf{f})$.

To gain more information about molecules interacting together in the lattices of cis-Cu(II) complex, HSA and 2D-FP were performed employing the crystallographic information file (CIF) data through CrystalExplorer software [35-40]. The simulated results are demonstrated in Figure 7 with declarations of the $\mathrm{d}_{\text {norm }}$, shape index, and 2D-FP established in the range of -0.672 to 1.776 a.u. The presence of heteroatoms and aromatic rings with free lone/pi pair of electrons like $\mathrm{S}, \mathrm{Cl}$, and $\mathrm{Ph}$ in addition to polar hydro- 
gens in the backbone of the computed complex enhances the formation of many short contacts (Figure 7a). Generally, the surface structure of the cis-Cu(II) complex reflected the existence of ten red spots. The large red spot reflects the consistence of $\mathrm{H} \cdots \mathrm{Cl}(\mathrm{H}-$ bond) and $\mathrm{CH} \cdots \pi \mathrm{C}=\mathrm{N}$ interactions, whereas the small spots are due to the formation of $\mathrm{C}_{\mathrm{ph}}-\mathrm{H} \cdots \pi \mathrm{Ph}$ interactions. The shape index indicates the presence of both nucleophilic (shown in red) and electrophilic (shown in blue) functional groups on the surface of the molecule (Figure $7 \mathrm{~b}$ ). This supports the formation of $\mathrm{C}-\mathrm{H} \cdots \pi \mathrm{Ph}$ interactions as revealed by XRD results. Moreover, the atom-to-atom 2D-FP intermolecular contacts percentage plot reveals the $\mathrm{H} \cdots \mathrm{H}$ interaction with the largest percentage of contribution, while the $\mathrm{H} \cdots \mathrm{Cu}$ demonstrates the smallest percentage of contribution of $0.1 \%$ (Figure $7 \mathrm{c}$ ). The total 2D-FP of $\mathrm{H} \cdots$ atoms ratios analysis are illustrated as follows: $\mathrm{H} \cdots \mathrm{H}>\mathrm{C} \cdots \mathrm{H}>\mathrm{S} \cdots \mathrm{H}>$ $\mathrm{Cl} \cdots \mathrm{H}>\mathrm{N} \cdots \mathrm{H}>\mathrm{Cu} \cdots \mathrm{H}$.
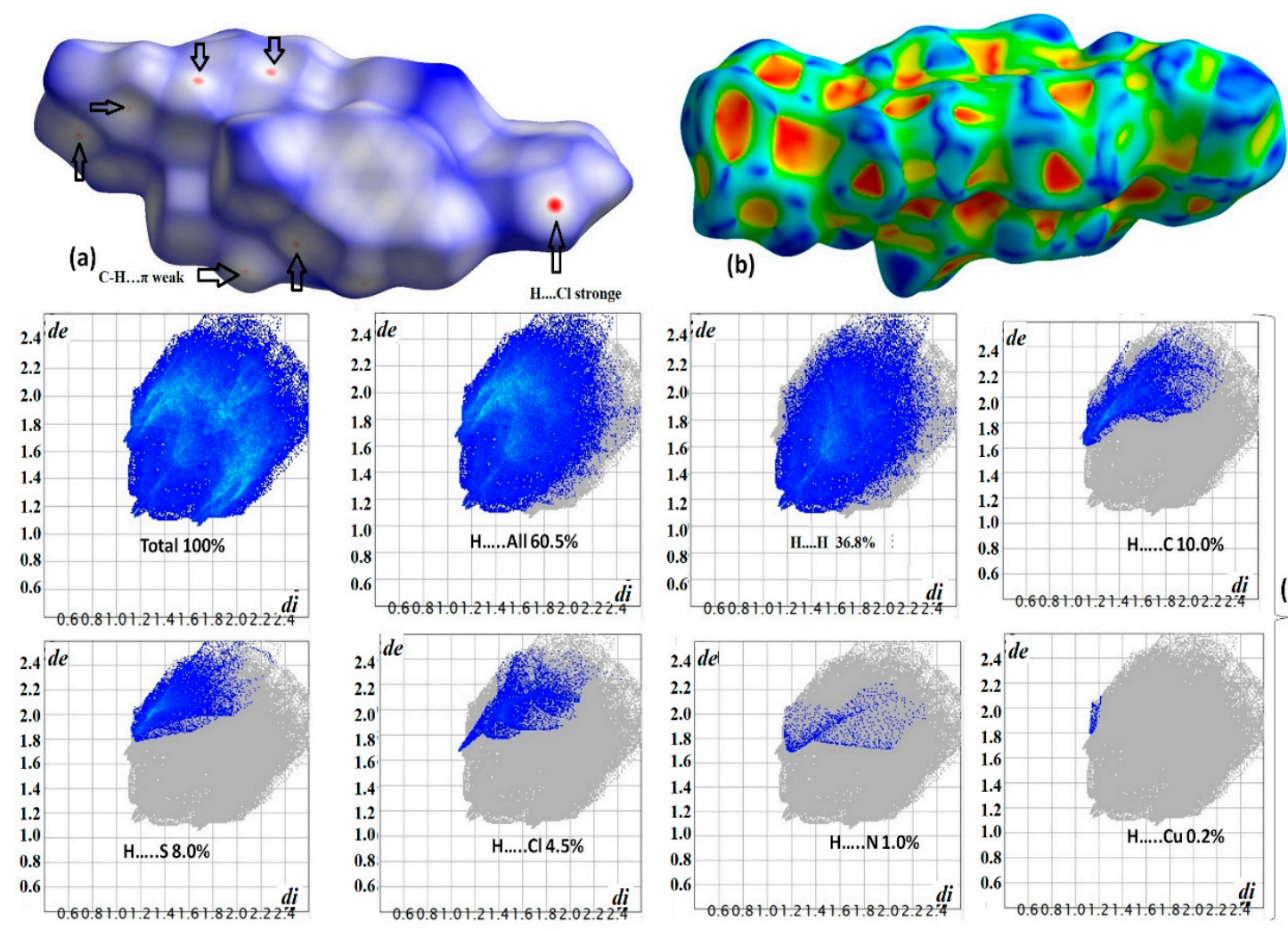

(b)
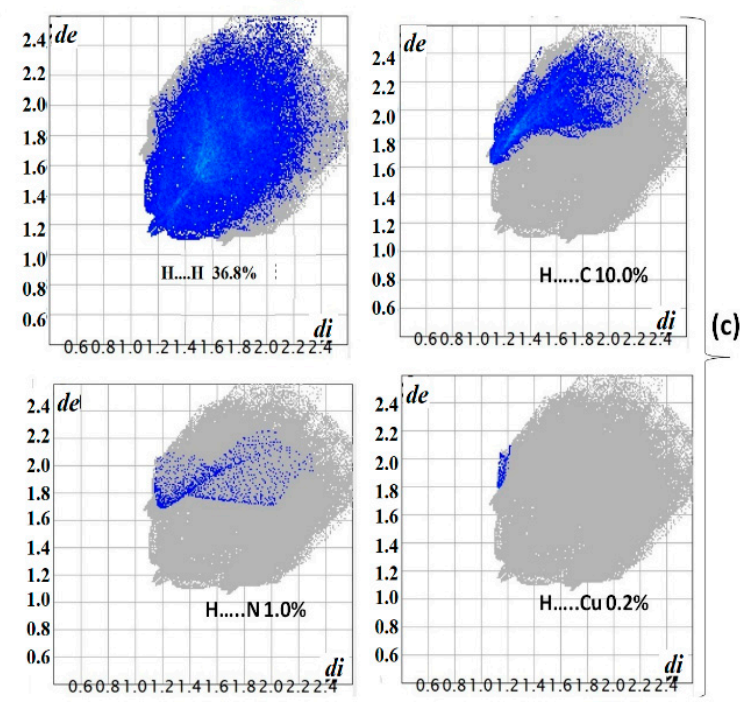

Figure 7. The $\mathrm{d}_{\text {norm }}(\mathbf{a})$, shape index (b), and two-dimensional fingerprint (2D-FP) intermolecular contacts over the complex surface $(\mathbf{c})$.

The MEP of the complex provided electrophilic and/or nucleophilic data about the surface. For instance, the position and strength of $\mathrm{H}$-bond interactions can be estimated depending on the color around the functional groups, which reflect the electronic density [28-33]. The analyzed complex showed a potential decrease in the following order: blue $>$ cyan $>$ green $>$ yellow $>$ orange $>$ red. The MEP also reflected the $\mathrm{Cl}, \mathrm{N}$, and $\mathrm{S}$ atoms with the highest nucleophilic sites (red color). Meanwhile, Ph rings are labeled with yellow, indicating moderate nucleophilic sites, whereas the green color reflects the neutral functional groups. The electrophilic sites are localized to the protons of phenyl and alkene, as exemplified in Figure 8. Therefore, non-classical C- $\mathrm{H} \cdots \pi$ and $\mathrm{C}-\mathrm{H} \cdots \mathrm{Cl}$ interactions are observed, revealing a consistence with HSA and XRD outcomes. 


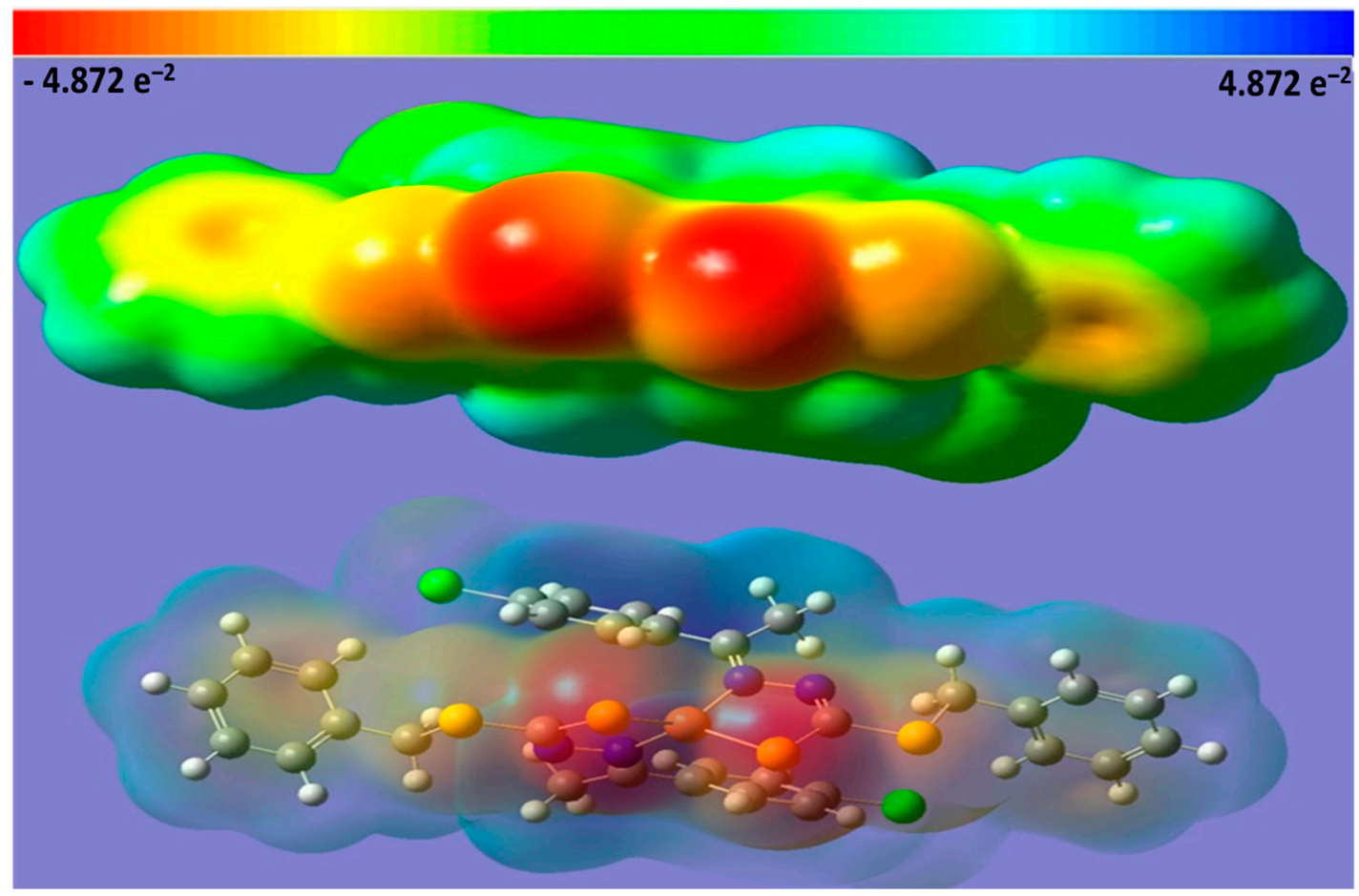

Figure 8. Molecular electrostatic potential (MEP) of the cis-Cu(II) complex.

\subsection{Thermogravimetric Analysis}

In order to demonstrate the thermal stability and material purity of the new metal complex, thermal gravimetric analysis (TGA) of the cis- $\mathrm{Cu}$ (II) compound was studied in an open atmosphere with a heat rate of $5^{\circ} \mathrm{C} / \mathrm{min}$ (Figure $9 \mathrm{a}$ ).

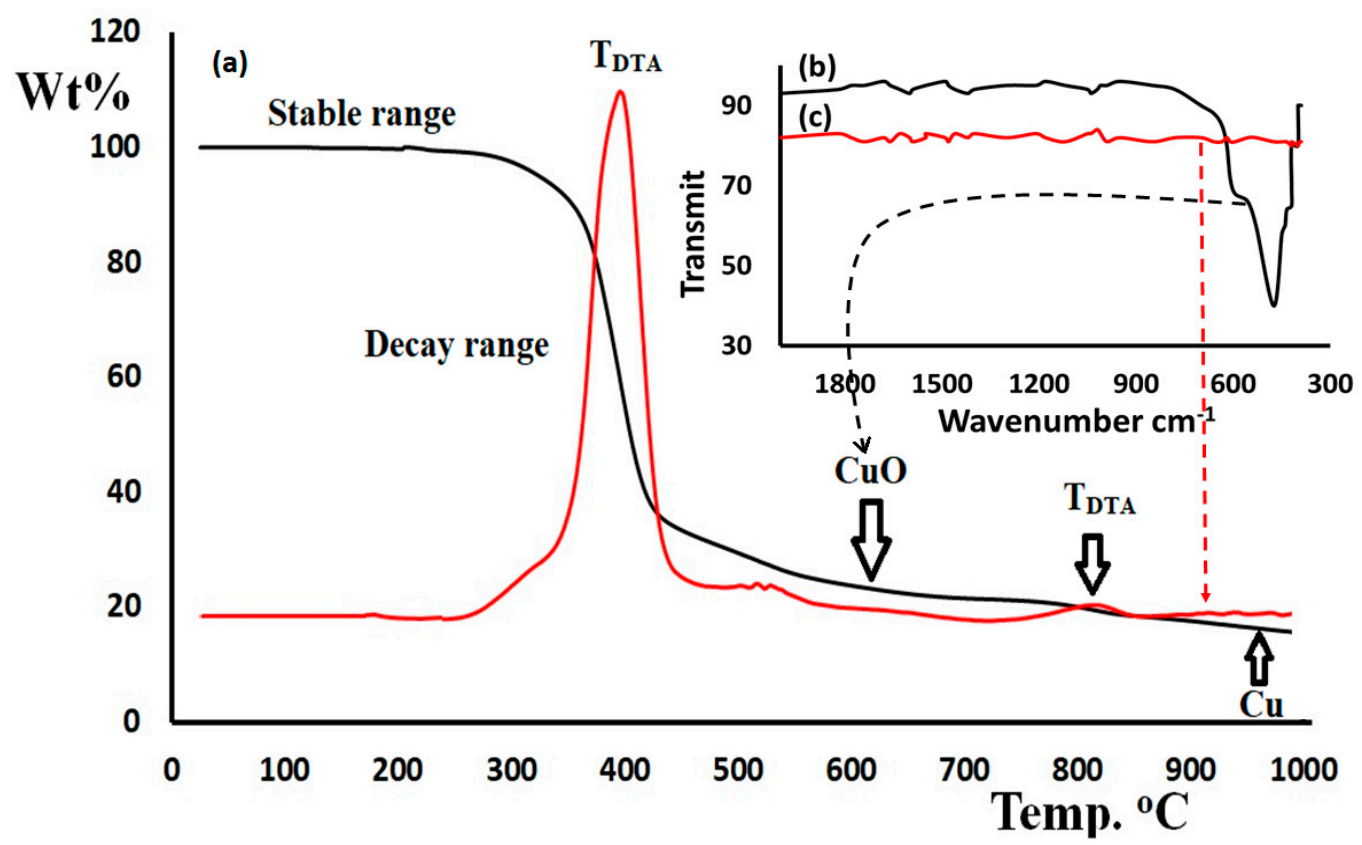

Figure 9. TG-DTA of the cis-Cu(II) complex (a), FTIR of $\mathrm{CuO}(\mathbf{b})$, and $\mathrm{Cu}(\mathbf{c})$.

Figure 9 shows a high thermal stability of the complex, up to $\sim 300{ }^{\circ} \mathrm{C}$. Since no mass loss was detected between 50 and $180{ }^{\circ} \mathrm{C}$, the absence of coordinated or uncoordinated water molecules at the copper metal center supports the XRD result. The mass of the complex was observed to decay in a broad exothermic pattern, starting from $250{ }^{\circ} \mathrm{C}$ until 
completion at $500{ }^{\circ} \mathrm{C}$ with DTA $=380{ }^{\circ} \mathrm{C}$. The complex decomposed in one successive broad exothermic step as a simple thermal pattern. In this step, $80 \%$ of the mass was lost, while the entire organic moiety was de-structured from the metal center at $\sim 500{ }^{\circ} \mathrm{C}$, letting $20 \%$ of $\mathrm{CuO}$ as a residue, which has been confirmed by FTIR as a broad absorption, $v_{\mathrm{CuO}}=$ $440-520 \mathrm{~cm}^{-1}$ (as seen in Figure $9 \mathrm{~b}$ ). Furthermore, the $\mathrm{CuO}$ demonstrated stability between 500 and $800{ }^{\circ} \mathrm{C}$. Above $800{ }^{\circ} \mathrm{C}$ the metal oxide lost its $\mathrm{O}$ atom to produce pure $\mathrm{Cu}$ with an exothermic step at DTA $=810$ and $18 \%$ of pure $\mathrm{Cu}$ metal residue (equation 1 ). The FTIR of the final residue (Figure 9c) displayed, as expected, the absence of absorption due to the lack of functional groups.

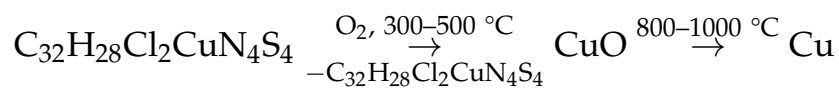

\section{Conclusions}

A new copper (II) complex was synthesized with high yield bearing two bidentate N,S-type ligand (benzyl (E)-2-(1-(4-chlorophenyl)ethylidene)hydrazine-1-carbodithioate). The molecular formula was emphasized via UV-Vis, CHN-EA, FT-IR, and FAB-MS analyses. $X$-ray diffraction revealed that the geometry of the complex is described as a tetrahedrally distorted square planar, in which the two N,S ligands are arranged in cis conformation. Additionally, the HSA and MEP results support the XRD packing in the formation of $\mathrm{C}-\mathrm{H} \cdots \mathrm{Cl}$ and $\mathrm{C}-\mathrm{H} \cdots \pi$ bonds with synthons and supramolecular interactions. The DFT/XRD bond length values are consistent, while a slightly lesser deviation is noted for angles. The thermal stability of the cis-Cu(II) complex is demonstrated to decompose to $\mathrm{CuO}$ above $300{ }^{\circ} \mathrm{C}$ in a single-step reaction mechanism.

Author Contributions: Formal analysis, A.B., A.F.A. and A.A.A.; data curation, H.L. and N.A.-Z.; review and editing, A.Z.; writing, I.W. All authors have read and agreed to the published version of the manuscript.

Funding: The authors extend their appreciation to the Researchers Supporting Project number (RSP-2021/396), King Saud University, Riyadh, Saudi Arabia.

Acknowledgments: The authors extend their sincere thanks to Ulrich Flörke Department Chemie, Universität Paderborn, Warburger Strasse 100, 33098 Paderborn, Germany for solving the crystal structure of the complex. Similar thanks go to the staff members at Chemistry department, Faculty of Science, Benghazi University, Huda Muftah Sheppaek, Wjdan Omar Algezzeri, and Iman Mahmoud, for their help in preparing the Schiff base, and special thanks go to Manchester salt and Catalysis Ltd, UK. The authors extend their appreciation to the Researchers Supporting Project number (RSP2021/396), King Saud University, Riyadh, Saudi Arabia.

Conflicts of Interest: The authors declare no conflict of interest.

\section{References}

1. Otero, L.; Vieites, M.; Boiani, L.; Denicola, A.; Rigol, C.; Opazo, L.; Olea-Azar, C.; Maya, J.D.; Morello, A.; Krauth-Siegel, R.I.; et al. Novel antitrypanosomal agents based on palladium nitrofurylthiosemicarbazone complexes: DNA and redox metabolism as potential therapeutic targets. J. Med. Chem. 2006, 49, 3322-3331. [CrossRef]

2. Rosu, T.; Gulea, A.; Nicolae, A.; Georgescu, R. Complexes of 3d(n) metal ions with thiosemicarbazones: Synthesis and antimicrobial activity. Molecules 2007, 12, 782-796. [CrossRef]

3. Pelosi, G.; Bisceglie, F.; Bignami, F.; Ronzi, P.; Schiavone, P.; Re, M.C.; Casoli, C.; Pilotti, E. Antiretroviral activity of thiosemicarbazone metal complexes. J. Med. Chem. 2010, 53, 8765-8769. [CrossRef]

4. Li, M.X.; Chen, C.L.; Zhang, D.; Niu, J.Y.; Ji, B.S. Mn(II), Co(II) and Zn(II) complexes with heterocyclic substituted thiosemicarbazones: Synthesis, characterization, X-ray crystal structures and antitumor comparison. Eur. J. Med. Chem. 2010, 45, 3169-3177. [CrossRef] [PubMed]

5. Ramachandran, E.; Kalaivani, P.; Prabhakaran, R.; Rath, N.P.; Brinda, S.; Poornima, P.; Padma, V.V.; Natarajan, K. Synthesis, $\mathrm{X}$-ray crystal structure, DNA binding, antioxidant and cytotoxicity studies of $\mathrm{Ni(ii)}$ and $\mathrm{Pd}(\mathrm{ii})$ thiose micarbazone complexes. Metallomics 2012, 4, 218-227. 
6. $\quad$ Lewis, N.A.; Liu, F.; Seymour, L.; Magnusen, A.; Erves, T.R.; Arca, J.F.; Beckford, F.A.; Venkatraman, R.; Gonzalez-Sarrias, A.; Fronczek, F.R.; et al. Synthesis, characterization, and preliminary in vitro studies of vanadium(IV) complexes with a Schiff base and thiosemicarbazones as mixed-ligands. Eur. J. Inorg. Chem. 2012, 2012, 664-677. [CrossRef] [PubMed]

7. Li, Y.S.; Peng, B.; Ma, L.; Cao, S.L.; Bai, L.L.; Yang, C.R.; Wan, C.Q.; Yan, H.J.; Ding, P.P.; Li, Z.F.; et al. Synthesis, crystal structures and antitumor activity of two platinum(II) complexes with methyl hydrazinecarbodithioate derivatives of indolin-2-one. Eur. J. Med. Chem. 2017, 127, 137-146. [CrossRef]

8. Li, M.X.; Zhang, L.Z.; Chen, C.L.; Niu, J.Y.; Ji, B.S. Synthesis, crystal structures, and biological evaluation of Cu(II) and Zn(II) complexes of 2-benzoylpyridine Schiff bases derived from S-methyl- and S-phenyldithiocarbazates. J. Inorg. Biochem. 2012, 106, 117-125. [CrossRef] [PubMed]

9. Sasmal, P.K.; Patra, A.K.; Chakravarty, A.R. Synthesis, structure, DNA binding and DNA cleavage activity of oxovanadium(IV) N-salicylidene-S-methyldithiocarbazate complexes of phenanthroline bases. J. Inorg. Biochem. 2008, 102, 1463-1472. [CrossRef]

10. Maia, P.I.; Fernandes, A.G.; Silva, J.J.; Andricopulo, A.D.; Lemos, S.S.; Lang, E.S.; Abram, U.; Deflon, V.M. Dithiocarbazate complexes with the $[\mathrm{M}(\mathrm{PPh} 3)] 2+(\mathrm{M}=\mathrm{Pd}$ or Pt) moiety: Synthesis, characterization and anti-Trypanosoma cruzi activity. J. Inorg. Biochem. 2010, 104, 1276-1282. [CrossRef]

11. Islam, M.A.A.A.; Tarafder, M.T.H.; Chanmiya Sheikh, M.; Ashraful Alam, M.; Zangrando, E. Coordination chemistry of [methyl3-(4-benzyloxyphenyl)methylene]dithiocarbazate with divalent metal ions: Crystal structures of the N,S Schiff base and of its bis-chelated nickel(II) complex. Transit. Met. Chem. 2011, 36, 531-537. [CrossRef]

12. Break, M.K.; Tahir, M.I.; Crouse, T.J.; Khoo, T.J. Synthesis, Characterization, and Bioactivity of Schiff Bases and Their Cd(2+), $\mathrm{Zn}(2+), \mathrm{Cu}(2+)$, and $\mathrm{Ni}(2+)$ Complexes Derived from Chloroacetophenone Isomers with S-Benzyldithiocarbazate and the X-Ray Crystal Structure of S-Benzyl- beta -N-(4-chlorophenyl)methylenedithiocarbazate. Bioinorg. Chem. Appl. 2013, $2013,362513$. [PubMed]

13. Hernandez, W.; Paz, J.; Carrasco, F.; Vaisberg, J.A.; Spodine, E.; Manzur, J.; Hennig, L.; Sieler, J.; Blaurock, S.; Beyer, L. Synthesis and Characterization of New Palladium(II) Thiosemicarbazone Complexes and Their Cytotoxic Activity against Various Human Tumor Cell Lines. Bioinorg. Chem. Appl. 2013, 2013, 524701. [CrossRef] [PubMed]

14. Ejidike, I.P.; Ajibade, P.A. Transition metal complexes of symmetrical and asymmetrical Schiff bases as antibacterial, antifungal, antioxidant, and anticancer agents: Progress and prospects. Rev. Inorg. Chem. 2015, 35, 191-224. [CrossRef]

15. Yazdanbakhsh, M.; Takjoo, R.; Frank, W.; Aghaei Kaju, A. The preparation, spectroscopic characterization and X-ray crystal structures of the pyrrole-2-carboxaldehyde Schiff base of S-allyldithiocarbazate (HL) and its nickel(II) complex ([Ni(L)2]). J. Coord. Chem. 2009, 62, 3651-3660. [CrossRef]

16. Bakherad, M.; Keivanloo, A.; Samangooei, S. Solvent-free Heck and copper-free Sonogashira cross-coupling reactions catalyzed by a polystyrene-anchored $\mathrm{Pd}(\mathrm{II})$ phenyldithiocarbazate complex. Tetrahedron Lett. 2012, 53, 5773-5776. [CrossRef]

17. Basha, M.T.; Chartres, J.D.; Pantarat, N.; Ali, M.A.; Mirza, A.H.; Kalinowski, D.S.; Richardson, D.R.; Bernhardt, P.V. Heterocyclic dithiocarbazate iron chelators: Fe coordination chemistry and biological activity. Dalton Trans. 2012, 41, 6536-6548. [CrossRef]

18. Takjoo, R.; Centore, R.; Hayatolgheibi, S.S. Mixed ligand complexes of cadmium(II) and copper(II) dithiocarbazate: Synthesis, spectral characterization, X-ray crystal structure. Inorg. Chim. Acta 471 2018, 471, 587-594. [CrossRef]

19. Mumit, M.A.; Pal, T.K.; Alam, M.A.; Islam, M.A.A.A.; Paul, S.; Sheikh, M.C. DFT studies on vibrational and electronic spectra, HOMO-LUMO, MEP, HOMA, NBO and molecular docking analysis of benzyl-3-N-(2,4,5-trimethoxyphenylmethylene)hydrazinecarbodithioate. J. Mol. Struct. 2020, 1220, 128715. [CrossRef]

20. Santra, A.; Brandao, P.; Mondal, G.; Bera, P.; Jana, A.; Bhattacharyya, I.; Pramanik, C.; Bera, P. Monomeric and dimeric cadmium(II) complexes of S-alkyl/aryl dithiocarbazate as single-source precursors for cadmium sulfide nanoparticles: An experimental, theoretical interpretation in the stability of precursor and visible light dye degradation study. Inorg. Chim. Acta. 2020, 501, 119315. [CrossRef]

21. Cox, D.N.; Mingos, D.M.P.; Hoffmann, R. Extended Hückel molecular-orbital calculations on dodecahedral metalloboranes which do not conform to the polyhedral skeletal electron-pair theory. J. Chem. Soc. Dalton Trans. 1981, 1788-1797. [CrossRef]

22. Abe, Y.; Nakazima, N.; Tanase, T.; Katano, S.; Mukai, H.; Ohta, K. Syntheses, Structures, and Mesomorphism of a Series of Cu(II) Salen Complexes with 4-Substituted Long Alkoxy Chains. Mol. Cryst. Liq. Cryst. 2007, 466, 129-147. [CrossRef]

23. Morris, R.J.; Girolami, G.S. A square-planar oxo-alkyl of manganese(III). Synthesis and X-ray crystal structure of $\left\{\mathrm{Li}_{2}\left[\mathrm{MnOMe}_{3}\right] \cdot 2 \mathrm{Li}_{2}(\mathrm{Meacac}) \cdot \mathrm{tmed}\right\}_{2}$. Polyhedron 1988, 7, 2001-2008. [CrossRef]

24. Turner, M.J.; McKinnon, J.J.; Wolff, S.K.; Grimwood, D.J.; Spackman, P.R.; Jayatilaka, D.; Spackman, M.A. CrystalExplorer 17; University of Western: Perth, Australia, 2017.

25. Frisch, M.J.; Trucks, G.W.; Schlegel, H.B.; Scuseria, G.E.; Robb, M.A.; Cheeseman, J.R.; Gonzalez, J.A.; Pople, J.A. Gaussian 09, Revision E.01; Gaussian, Inc.: Wallingford, CT, USA, 2009.

26. Burla, M.C.; Caliandro, R.; Camalli, M.; Carrozzini, B.; Cascarano, G.L.; Caro, L.D.; Giacovazzo, C.; Polidori, G.; Spagna, R. SIR2004: An improved tool for crystal structure determination and refinement. J. Appl. Cryst. 2005, 38, 381-388. [CrossRef]

27. Sheldrick, G.M. SHELX-97, Release 97-2; University of Goettingen: Goettingen, Germany, 1998.

28. Akbar Ali, M.; Tarafdar, M.H.H. Metal complexes of sulphur and nitrogen-containing ligands: Complexes of s-benzyldithiocarbazate and a schiff base formed by its condensation with pyridine-2-carboxaldehyde. J. Inorg. Nucl. Chem. 1977, 39, 1785-1791. [CrossRef] 
29. Guerraoui, A.; Djedouani, A.; Jeanneau, E.; Boumaza, A.; Alsalme, A.; Zarrouk, A.; Salih, K.S.M.; Warad, I. Crystal structure and spectral of new hydrazine-pyran-dione derivative: DFT enolhydrazone tautomerization via zwitterionic intermediate, hirshfeld analysis and optical activity studies. J. Mol. Struct. 2020, 1220, 128728-128738. [CrossRef]

30. Tabti, S.; Djedouani, A.; Aggoun, D.; Warad, I.; Rahmouni, S.; Romdhane, S.; Fouzi, H. New Cu (II), Co(II) and Ni(II) complexes of chalcone derivatives: Synthesis, X-ray crystal structure, electrochemical properties and DFT computational studies. J. Mol. Struct. 2018, 1155, 11-20. [CrossRef]

31. Becke, A.D. Density-functional exchange-energy approximation with correct asymptotic behavior. Phys. Rev. A 1988, 38, 3098-3100. [CrossRef] [PubMed]

32. Lee, C.; Yang, W.; Parr, R.G. Development of the Colle-Salvetti correlation-energy formula into a functional of the electron density. Phys. Rev. B 1988, 37, 785-789. [CrossRef] [PubMed]

33. Flörke, U.; Boshaala, A. Experimental Crystal Structure Determination. CSDCommun. CCDC 2016, 1503558. Available online: https://www.ccdc.cam.ac.uk/structures/search?id=doi:10.5517/ccdc.csd.cc1mgkwj\&sid=DataCite (accessed on 15 September 2021). [CrossRef]

34. Hema, M.K.; Karthik, C.S.; Warad, I.; Lokanath, N.K.; Zarrouk, A.; Kumara, K.; Pampa, K.J.; Mallu, P. Regular square planer bis(4,4,4-trifluoro-1-(thiophen-2-yl)butane-1,3-dione)/copper(II) complex: Trans/cis-DFT isomerization, crystal structure, thermal, solvatochromism, hirshfeld surface and DNA-binding analysis. J. Mol. Struct. 2018, 1157, 69-77. [CrossRef]

35. Warad, I.; Musameh, S.; Badran, I.; Nassar, N.N.; Brandao, P.; Tavares, C.J.; Barakat, A. Synthesis, solvatochromism and crystal structure of trans- $\left[\mathrm{Cu}\left(\mathrm{Et}_{2} \mathrm{NCH}_{2} \mathrm{CH}_{2} \mathrm{NH}_{2}\right)_{2} \cdot \mathrm{H}_{2} \mathrm{O}\right]\left(\mathrm{NO}_{3}\right)_{2}$ complex: Experimental with DFT combination. J. Mol. Struct. 2017, 11148, 328-338. [CrossRef]

36. Aouad, M.R.; Messali, M.; Rezki, N.; Al-Zaqri, N.; Warad, I. Single proton intramigration in novel 4-phenyl-3-((4-phenyl-1H-1,2,3triazol-1-yl)methyl)-1H-1,2,4-triazole-5(4H)-thione: XRD-crystal interactions, physicochemical, thermal, Hirshfeld surface, DFT realization of thiol/thione tautomerism. J. Mol. Liq. 2018, 264, 621-630. [CrossRef]

37. Badran, I.; Abdallah, L.; Mubarakeh, R.; Warad, I. Effect of alkyl derivation on the chemical and antibacterial properties of newly synthesized Cu(II)-diamine complexes. Mor. J. Chem. 2019, 7, 161-170.

38. Hema, M.K.; Karthik, C.S.; Lokanath, N.K.; Mallu, P.; Zarrouk, A.; Salih, K.S.M.; Warad, I. Synthesis of novel Cubane $\left[\mathrm{Ni}_{4}(\mathrm{O} \cap \mathrm{O})_{4}\left(\mathrm{OCH}_{3}\right)_{4}(\mathrm{OOH})_{4}\right]$ cluster: XRD/HSA-interactions, spectral, DNA-binding, docking and subsequent thermolysis to $\mathrm{NiO}$ nanocrystals. J. Mol. Liq. 2020, 315, 113756-113766. [CrossRef]

39. Al-Zaqri, N.; Salih, K.S.M.; Awwadi, F.F.; Alsalme, A.; Alharthi, F.A.; Alsyahi, A.; Ali, A.A.; Zarrouk, A.; Aljohani, M.; Chetouni, A.; et al. Synthesis, physicochemical, thermal, and XRD/HSA interactions of mixed [Cu(Bipy)(Dipn)](X) $)_{2}$ complexes: DNA binding and molecular docking evaluation. J. Coord. Chem. 2020, 73, 3236-3248. [CrossRef]

40. Badran, I.; Tighadouini, S.; Radi, S.; Zarrouk, A.; Warad, I. Experimental and first-principles study of a new hydrazine derivative for DSSC applications. J. Mol. Struct. 2021, 1229, 129799. [CrossRef] 